SRNL-STI-2013-00034

Revision 0

Keywords: $M C U, A R P, I S D P$

Retention: Permanent

\title{
Interim Salt Disposition Program Macrobatch 6 Tank 21H \\ Qualification Monosodium Titanate and Cesium Mass Transfer Tests
}

\author{
A. L. Washington, II \\ T. B. Peters \\ S. D. Fink
}

February 2013

Savannah River National Laboratory

Savannah River Nuclear Solutions

Aiken, SC 29808

Prepared for the U.S. Department of Energy under

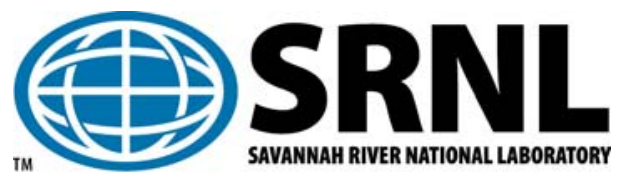
contract number DE-AC09-08SR22470. 
SRNL-STI-2013-00034

Revision 0

\section{DISCLAIMER}

This work was prepared under an agreement with and funded by the U.S. Government. Neither the U.S. Government or its employees, nor any of its contractors, subcontractors or their employees, makes any express or implied:

1. warranty or assumes any legal liability for the accuracy, completeness, or for the use or results of such use of any information, product, or process disclosed; or

2. representation that such use or results of such use would not infringe privately owned rights; or

3. endorsement or recommendation of any specifically identified commercial product, process, or service.

Any views and opinions of authors expressed in this work do not necessarily state or reflect those of the United States Government, or its contractors, or subcontractors.

\section{Printed in the United States of America}

Prepared for

U.S. Department of Energy 


\section{REVIEWS AND APPROVALS}

\section{AUTHORS:}

A. L. Washington, II, Author, SRNL/ACP

Date

T. B. Peters, Author, SRNL/ACP

Date

TECHNICAL REVIEW:

C. A. Nash, Technical Reviewer, SRNL/ACP

Date

APPROVAL:

S. D. Fink, SRNL/SASP, Manager

Date

F. M. Pennebaker, SRNL/ACP, Manager

Date

S. L. Marra, SRNL/E\&CPT Research Programs, Manager

Date

K. H. Subramanian, DWPF Regulatory Engineering, Manager

Date

M. T. Keefer, Tank Farm Facility Engineering, Manager

Date

E. J. Freed, DWPF Facility Engineering, Manager

Date 
SRNL-STI-2013-00034

Revision 0

\section{EXECUTIVE SUMMARY}

Savannah River National Laboratory (SRNL) performed experiments on qualification material for use in the Interim Salt Disposition Program (ISDP) Batch 6 processing. This qualification material was a set of six samples from Tank 21H in October 2012.

This sample was used as a real waste demonstration of the Actinide Removal Process (ARP) and the Extraction-Scrub-Strip (ESS) tests process. The Tank $21 \mathrm{H}$ sample was contacted with a reduced amount $(0.2 \mathrm{~g} / \mathrm{L})$ of MST and characterized for strontium and actinide removal at 0 and 8 hour time intervals in this salt batch.

${ }^{237} \mathrm{~Np}$ and ${ }^{243} \mathrm{Am}$ were both observed to be below detection limits in the source material, and so these results are not reported in this report. The plutonium and uranium samples had decontamination factor (DF) values that were on par or slightly better than we expected from Batch 5. The strontium DF values are slightly lower than expected but still in an acceptable range. The Extraction, Scrub, and Strip (ESS) testing demonstrated cesium removal, stripping and scrubbing within the acceptable range. Overall, the testing indicated that cesium removal is comparable to prior batches at MCU. 


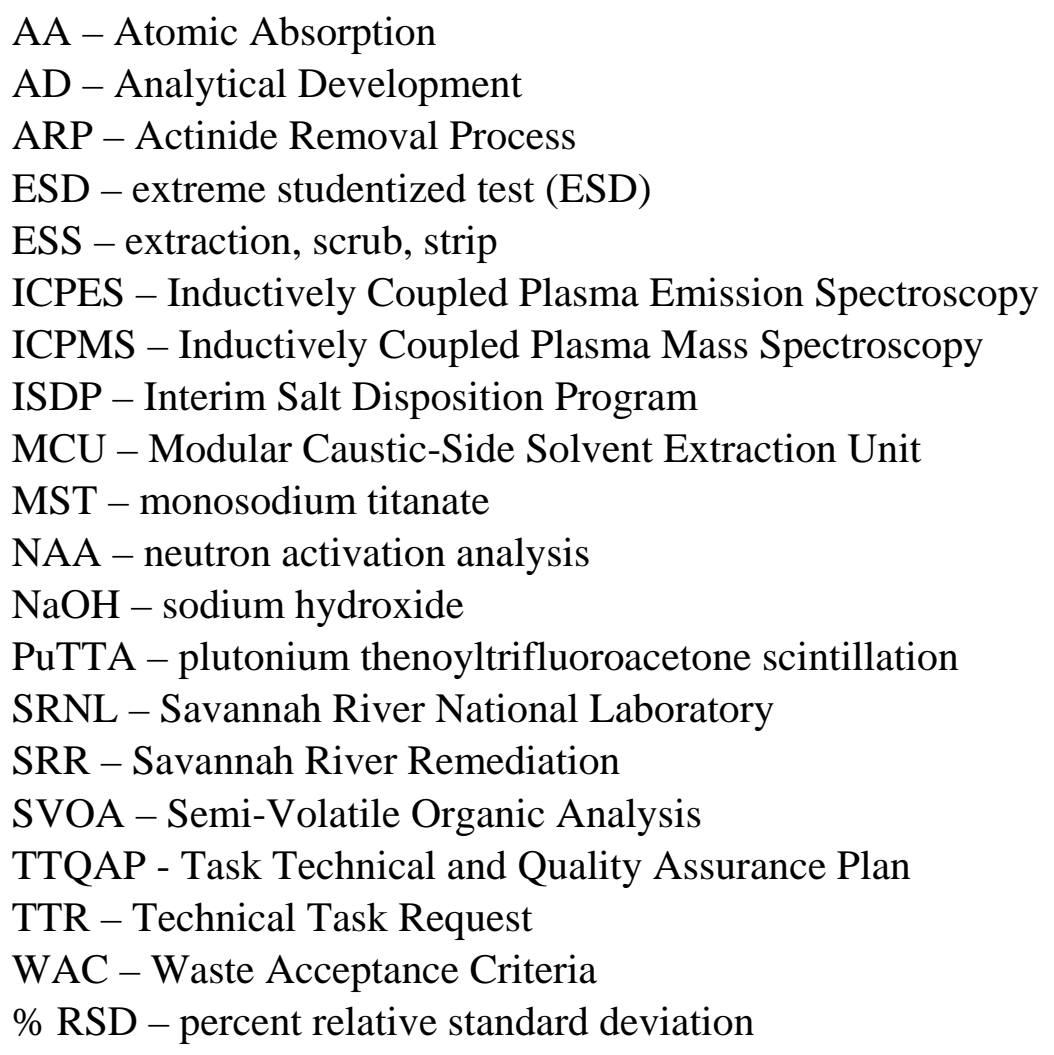


SRNL-STI-2013-00034

Revision 0

\subsection{Introduction}

This report details the results of the Actinide Removal Process (ARP) and ExtractionScrub-Strip (ESS) demonstrations for Macrobatch (Salt Batch) 6 of the Interim Salt Disposition Program (ISDP). This small scale radioactive demonstration provides working data for the process chemistry being performed on the salt batch.

Previous documents i, ii cover initial and subsequent characterization which include analytical results. This work was specified by Task Technical Request (TTR) ${ }^{\mathrm{iii}}$ and by Task Technical and Quality Assurance Plan (TTQAP). ${ }^{\text {iv }}$

For this macrobatch, Tank $21 \mathrm{H}$ material is used as the preparation tank. This material will be transferred to Tank $49 \mathrm{H}$ where it will be combined with the heel from Macrobatch 5. In this qualification effort for Macrobatch 6, only samples from Tank $21 \mathrm{H}$ have been analyzed. The qualification and tank strategy indicates that analysis of Tank $49 \mathrm{H}$ is not needed as the material was qualified for Macrobatch $5 .^{\mathrm{v}}$

Details for the work are contained in controlled laboratory notebooks. ${ }^{\mathrm{vi}}$

\subsection{Experimental Procedure}

Six Tank 21H samples (i.e., dip sample bottles HTF-21-12-96, HTF-21-12-97, HTF-2112-98, HTF-21-12-99, HTF-21-12-100, and HTF-21-12-101) arrived at SRNL on October 3, 2012. In accordance to the TTQAP, the samples were visually inspected upon arrival to SRNL for solids and density measurements were performed. ${ }^{\text {iv }}$ Both analyses were performed with no anomalies reported. These samples were then combined into one composite bottle for further use.

\subsection{MST Sorption Test}

The Tank $21 \mathrm{H}$ composite material was optically clear with no visible indication of solids; thus, the solution was not filtered nor was the turbidity measured. For the MST Sorption Test, approximately $400 \mathrm{~mL}$ of the ISDP6 Tank $21 \mathrm{H}$ material was obtained for processing. The composite salt solution was previously measured with a density of 1.304 $\mathrm{g} / \mathrm{mL}$ at $\left(20^{\circ} \mathrm{C}\right)$.

$200 \mathrm{~mL}$ of the salt solution was placed into the experiment bottle, while the remainder ( $\sim 200 \mathrm{~mL}$ ) was placed into the control bottle. Both bottles had magnetic stir bars added to provide sufficient mixing for batch contact tests. The target concentration for MST was $0.2 \mathrm{~g} / \mathrm{L}$, about half what is normally used. The reduction of MST addition is reflected by a change in the facility to improve material throughput. Personnel added $0.2753 \mathrm{~g}$ of MST solids in a $14.5 \mathrm{wt} \%$ solution from an archived batch of material from Blue Grass Chemical Specialties MST-2723 to the experiment bottle. This time was recorded and designated as time 0 . Throughout the course of the test, agitation and temperature control $\left(25 \pm 3{ }^{\circ} \mathrm{C}\right)$ were provided. 
During the experiment, samples were collected in triplicate from each of the two bottles at 0 and 8 hours. For the sample at 0 hours, sampling occurred immediately prior to MST addition solely from the control bottle. For the sample at 8 hours, sampling occurred immediately at the 8 hour mark preventing additional MST sorption. Personnel filtered the samples using $0.45 \mu \mathrm{m}$ Versapor тм syringe filters, removed the samples from the cells for analysis, and analyzed for plutonium (PuTTA), ${ }^{90} \mathrm{Sr}$ (beta scintillation), and ${ }^{238} \mathrm{U}$ (ICPMS). Samples were sent to AD with moderate dilution, and those dilutions are accounted for in the results section. This test uses the same protocol as used in the previous Macrobatch testing. ${ }^{\text {vii }}$

\subsection{ESS Demonstration}

For the ESS Demonstration, material from the MST Sorption Demonstration was used. For this test, the researchers used a nominal starting volume of $90 \mathrm{~mL}$ of aqueous feed and $30 \mathrm{~mL}$ of fresh, unused solvent (S2-D1-YESBOB-T-WI). ${ }^{\Upsilon}$ This test uses the same protocol as used in the previous Macrobatch testing. ${ }^{\text {vii }}$

\subsection{Results and Discussion}

\subsection{Results from the MST Sorption Test}

For the MST Sorption Test, technicians used $200 \mathrm{~mL}$ of a composite made from Tank $21 \mathrm{H}$ samples (see section 2.1). The composite was not filtered and no observation of gross formation of solids was made. The turbidity was not measured.

${ }^{237} \mathrm{~Np}$ and ${ }^{243} \mathrm{Am}$ were both observed to be below detection limits in the source material, and so these results are not reported. Samples were sent to Analytical Development (AD) with moderate dilution to remove material from the cells. Those dilutions are accounted for in the results section. Adsorption of specific elements is discussed in the following sections.

This was the first macrobatch test in utilizing MST at the lower concentration of $0.2 \mathrm{~g} / \mathrm{L}$. The data in this report correlates well with a previous report demonstrating the effectiveness of MST at this concentration. In fact, the DF values for each element tested were similar to or better than expected based on previous tests. viii

\subsubsection{Plutonium Results}

Table 1 shows the plutonium results for ${ }^{238} \mathrm{Pu}$ at 0 and 8 hours. The DF values for ${ }^{238} \mathrm{Pu}$ are shown in Table 2 for both the 0 hour and triplicate 8 hour samples. Table 3 shows the plutonium results for ${ }^{239 / 240} \mathrm{Pu}$. The DF values for ${ }^{239 / 240} \mathrm{Pu}$ are shown in Table 4 for both the 0 hour and triplicate 8 hour samples. The error percentage values (shown in parentheses) in Table 1 and Table 3 are the analytical uncertainty associated with the measurement and does not include any contribution to uncertainty due to experimental and sampling methods. The last 8 hour control sample in ${ }^{238} \mathrm{Pu}$ data shown in Table 1 is a statistical outlier to the $99 \%$ confidence limit. This is determined by the Grubb's test using the extreme studentized deviate (ESD) method. ${ }^{\text {ix }}$

\footnotetext{
${ }^{\Upsilon}$ This batch of solvent was originally prepared with no extractant as S2-NOBOB-T-WI (see WSRC-NB-2005-00060). The extractant was added later (see WSRC-NB-2007-00054).
} 
In analyzing the $\mathrm{Pu}$ data, the DF values for Pu removal are very similar with average DF of 2.84 and 2.77 for the ${ }^{238} \mathrm{Pu}$ and ${ }^{239 / 240} \mathrm{Pu}$ data sets, respectively. The similarity in $\mathrm{Pu}$ removal indicates that the MST does not preferentially remove one isotope of Pu better than another.

Table 1. ${ }^{238} \mathrm{Pu}$ Concentrations in the MST Strike Filtrates

\begin{tabular}{|c|c|c|}
\hline \multirow{2}{*}{$\begin{array}{c}\text { Time } \\
\text { (hours) }\end{array}$} & \begin{tabular}{c} 
Experiment \\
\cline { 2 - 3 }
\end{tabular} & $\begin{array}{c}\text { Control } \\
{ }^{238} \mathrm{Pu}(\mathrm{pCi} / \mathrm{mL})\end{array}$ \\
\hline $0^{*}$ & $1.02 \mathrm{E}+04(4.46 \%)$ & $1.02 \mathrm{Pu}+04(\mathrm{pCi} / \mathrm{mL})$ \\
\hline $0^{*}$ & $1.06 \mathrm{E}+04(4.68 \%)$ & $1.06 \mathrm{E}+04(4.68 \%)$ \\
\hline $0^{*}$ & $1.05 \mathrm{E}+04(4.50 \%)$ & $1.05 \mathrm{E}+04(4.50 \%)$ \\
\hline 8 & $3.63 \mathrm{E}+03(5.28 \%)$ & $1.03 \mathrm{E}+04(4.50 \%)$ \\
\hline 8 & $3.69 \mathrm{E}+03(5.60 \%)$ & $1.06 \mathrm{E}+04(4.60 \%)$ \\
\hline 8 & $3.67 \mathrm{E}+03(5.13 \%)$ & $8.61 \mathrm{E}+03(4.50 \%)$ \\
\hline
\end{tabular}

$*$ The time $=0$ data are the same data point.

Table 2 lists the decontamination factors (DF) after the MST strike.

Table 2. ${ }^{238}$ Pu Decontamination Factors (DF) over Time

\begin{tabular}{|c|c|c|}
\hline \multirow{2}{*}{ Time (hours) } & Experiment & Control \\
\cline { 2 - 3 } & DF & DF \\
\hline 0 & 0 & 0 \\
\hline 8 & 2.87 & 1.01 \\
\hline 8 & 2.82 & 0.98 \\
\hline 8 & 2.84 & 1.21 \\
\hline
\end{tabular}

Table 3. ${ }^{239 / 240} \mathrm{Pu}$ Concentrations in the MST Strike Filtrates

\begin{tabular}{|c|c|c|}
\hline \multirow{2}{*}{$\begin{array}{c}\text { Time } \\
\text { (hours) }\end{array}$} & \begin{tabular}{c} 
Experiment \\
\cline { 2 - 3 }
\end{tabular}${ }^{239 / 240} \mathrm{Pu}(\mathrm{pCi} / \mathrm{mL})$ & Control \\
\hline $0^{*}$ & $9.16 \mathrm{E}+02(4.86 \%)$ & $9.16 \mathrm{E}+02(4.86 \%)$ \\
\hline $0^{*}$ & $8.45 \mathrm{E}+02(6.48 \%)$ & $8.45 \mathrm{E}+02(6.48 \%)$ \\
\hline $0^{*}$ & $8.70 \mathrm{E}+02(5.21 \%)$ & $8.70 \mathrm{E}+02(5.21 \%)$ \\
\hline 8 & $3.49 \mathrm{E}+02(5.28 \%)$ & $8.91 \mathrm{E}+02(4.50 \%)$ \\
\hline 8 & $3.03 \mathrm{E}+02(5.60 \%)$ & $8.45 \mathrm{E}+02(4.60 \%)$ \\
\hline 8 & $3.01 \mathrm{E}+02(5.13 \%)$ & $8.77 \mathrm{E}+02(4.50 \%)$ \\
\hline
\end{tabular}

*The time $=0$ data are the same data point. 
Table 4 lists the decontamination factors (DF) after the MST strike.

Table 4. ${ }^{239 / 240} \mathrm{Pu}$ Decontamination Factors (DF) over Time

\begin{tabular}{|c|c|c|}
\hline Time (hours) & Experiment & Control \\
\hline & DF & DF \\
\hline 0 & 0 & 0 \\
\hline 8 & 2.51 & 0.98 \\
\hline 8 & 2.89 & 1.04 \\
\hline 8 & 2.91 & 1.00 \\
\hline
\end{tabular}

\subsubsection{Strontium Results}

Researchers analyzed the filtered samples for ${ }^{90} \mathrm{Sr}$. Table 5 shows the strontium results for ${ }^{90} \mathrm{Sr}$. The error percentage values (shown in parentheses) in Table 5 are the analytical uncertainty associated with the measurement and does not include any contribution to uncertainty due to experimental and sampling methods. The ${ }^{90} \mathrm{Sr}$ samples are analyzed separately for separation yield by neutron activation analysis (NAA) and for ${ }^{90} \mathrm{Sr}$ concentration by beta scintillation counting after the ${ }^{90} \mathrm{Sr}$ column separation. In the case of the control values for the 8-hour samples, the sample still contained a significant amount of ${ }^{137} \mathrm{Cs}$ from the column separations. The ${ }^{137} \mathrm{Cs}$ increases the gamma background for the NAA measurement of the stable ${ }^{90} \mathrm{Sr}$ carrier used to determine ${ }^{90} \mathrm{Sr}$ recoveries of the separation. The resulting decrease in the signal to noise ratio raised the uncertainty values of the ${ }^{90} \mathrm{Sr}$ measurements for some of the samples.

Table 5. ${ }^{90} \mathrm{Sr}$ Concentrations in the MST Strike Filtrates

\begin{tabular}{|c|c|c|}
\hline \multirow{2}{*}{$\begin{array}{c}\text { Time } \\
\text { (hours) }\end{array}$} & Experiment & Control \\
\cline { 2 - 3 } & ${ }^{90} \mathrm{Sr}(\mathrm{pCi} / \mathrm{mL})$ & ${ }^{90} \mathrm{Sr}(\mathrm{pCi} / \mathrm{mL})$ \\
\hline $0^{*}$ & $3.26 \mathrm{E}+05(25.00 \%)$ & $3.26 \mathrm{E}+05(25.00 \%)$ \\
\hline $0^{*}$ & $1.87 \mathrm{E}+05(9.76 \%)$ & $1.87 \mathrm{E}+05(9.76 \%)$ \\
\hline $0^{*}$ & $2.18 \mathrm{E}+05(8.68 \%)$ & $2.18 \mathrm{E}+05(8.68 \%)$ \\
\hline 8 & $1.02 \mathrm{E}+04(9.88 \%)$ & $3.43 \mathrm{E}+05(28.70 \%)$ \\
\hline 8 & $8.14 \mathrm{E}+03(10.50 \%)$ & $3.33 \mathrm{E}+05(44.00 \%)$ \\
\hline 8 & $6.34 \mathrm{E}+03(9.72 \%)$ & $2.43 \mathrm{E}+05(20.20 \%)$ \\
\hline
\end{tabular}

*The time $=0$ data are the same data point. 
Table 6 lists the decontamination factors (DF) after the MST strike.

Table 6. ${ }^{90} \mathrm{Sr}$ Decontamination Factors (DF) over Time

\begin{tabular}{|c|c|c|}
\hline \multirow{2}{*}{ Time (hours) } & Experiment & Control \\
\cline { 2 - 3 } & DF & DF \\
\hline $0 *$ & 0 & 0 \\
\hline 8 & 24 & 0.71 \\
\hline 8 & 30 & 0.73 \\
\hline 8 & 38 & 1.00 \\
\hline \multicolumn{2}{|c}{$*=$ Time 0 is the baseline }
\end{tabular}

\subsubsection{Uranium Results}

Researchers analyzed the filtered samples for ${ }^{238} \mathrm{U}$. Table 7 shows the uranium results for ${ }^{238} \mathrm{U}$. The uranium concentration is consistent with what was seen in the Macrobatch 5 samples. The DF is nearly 1 for both the control and experimental values. The error percentage values (shown in parentheses) in Table 7 are the analytical uncertainty associated with the measurement and does not include any contribution to uncertainty due to experimental and sampling methods.

\section{Table 7. ${ }^{238} \mathrm{U}$ Concentrations in the MST Strike Filtrates}

\begin{tabular}{|c|c|c|}
\hline \multirow{2}{*}{$\begin{array}{c}\text { Time } \\
\text { (hours) }\end{array}$} & \begin{tabular}{c} 
Experiment \\
\cline { 2 - 3 }
\end{tabular} & \begin{tabular}{c} 
Control \\
\hline${ }^{238} \mathrm{U}(\mathrm{pCi} / \mathrm{mL})$
\end{tabular} \\
\hline $0^{*}$ & $6.16 \mathrm{E}+00(1.08 \%)$ & $6.16 \mathrm{E}+00(1.08 \%)$ \\
\hline $0 *$ & $6.69 \mathrm{E}+00(.280 \%)$ & $6.69 \mathrm{E}+00(.280 \%)$ \\
\hline 8 & $6.19 \mathrm{E}+00(2.55 \%)$ & $6.19 \mathrm{E}+00(2.55 \%)$ \\
\hline 8 & $6.06 \mathrm{E}+00(2.19 \%)$ & $6.60 \mathrm{E}+00(1.31 \%)$ \\
\hline 8 & $5.92 \mathrm{E}+00(1.68 \%)$ & $6.28 \mathrm{E}+00(0.116 \%)$ \\
\hline & $6.04 \mathrm{E}+00(4.38 \%)$ & $6.42 \mathrm{E}+00(2.74 \%)$ \\
\hline
\end{tabular}

$*$ The time $=0$ data are the same data point.

Table 8 lists the DF after the MST strike.

Table 8. ${ }^{238}$ U Decontamination Factors (DF) Over Time

\begin{tabular}{|c|c|c|}
\hline \multirow{2}{*}{ Time (hours) } & Experiment & Control \\
\cline { 2 - 3 } & DF & DF \\
\hline $0 *$ & 0 & 0 \\
\hline 8 & 1.05 & 0.96 \\
\hline 8 & 1.07 & 1.01 \\
\hline 8 & 1.05 & 0.99 \\
\hline \multicolumn{2}{|c}{$*=$ Time 0 is the baseline } \\
r
\end{tabular}




\subsection{Results from the ESS Test}

For the ESS Test, filtrate from the MST Sorption Test was used. For this test, the researchers used a nominal starting volume of $90 \mathrm{~mL}$ of aqueous feed and $30 \mathrm{~mL}$ of fresh, unused solvent (S2-D1-YESBOB-T-WI). ${ }^{\Upsilon}$

Table 9 shows the results from the ESS Test, corrected to the normal process operating temperatures (i.e., $23{ }^{\circ} \mathrm{C}$ for extraction and $33{ }^{\circ} \mathrm{C}$ for scrubbing and stripping). As a comparison, the results from the previous macrobatch qualification ESS test (using the same solvent) in 2012 are displayed. ${ }^{\text {vii }}$

Table 9. Cesium Distribution Values for the ESS Test

\begin{tabular}{|c|c|c|c|c|c|c|}
\hline Material & Extraction & Scrub \#1 & Scrub \#2 & $\begin{array}{c}\text { Strip } \\
\# 1\end{array}$ & $\begin{array}{c}\text { Strip } \\
\# 2\end{array}$ & Strip \#3 \\
\hline Acceptable Range & $>8$ & $>0.6,<2$ & $>0.6,<2$ & $<0.2$ & $<0.16$ & $<0.16$ \\
\hline $\begin{array}{c}\text { S2-D1-YES BOB-T-WI, } \\
\text { ISDP 5 (previous test) }\end{array}$ & 16.0 & 1.57 & 0.953 & 0.0397 & 0.039 & 0.040 \\
\hline pH & & 7 & 3 & 3 & 5 & 5 \\
\hline $\begin{array}{c}\text { S2-D1-YES BOB-T-WI, } \\
\text { ISDP 6 (current test) }\end{array}$ & 9.14 & 2.716 & 0.800 & 0.0396 & 0.0184 & 0.0247 \\
\hline pH & & 9 & 4 & 5 & 4 & 5 \\
\hline
\end{tabular}

The current test shows acceptable values for all steps except Scrub \#1. This high value is not uncommon in Scrub\#1 (due to carryover of minor amounts of salt solution) and is not a matter of concern. ${ }^{\mathrm{x}}$ xi The purpose of two scrub steps is to offset the carryover on the salt solution. Therefore, high DFs in Scrub \#1 are very common to observe. Additionally, similar behavior has been observed in Strip \#1 from caustic carryover when the $\mathrm{pH}$ is shifted. The large difference in the DF in the extraction phase from ISDP 5 and ISDP 6 is directly attributed to mixing technique. ${ }^{\text {iii }}$ However, the value is still above the acceptable range indicating that the MCU process was performed correctly. From the bulk chemistry of the solution, an extraction DF of $\sim 13.7$ is predicted. ${ }^{\text {xiii }}$

\subsubsection{Strip Effluent and DSS Results}

During, and at the end of the ESS test, the gamma activity in the strip effluent and the decontaminated salt solution (DSS) was measured. The results are shown in Table 10.

Table 10. Strip Effluent and DSS Results

\begin{tabular}{|c|c|c|}
\hline Sample & ${ }^{\mathbf{1 3 7}}$ Cs activity (dpm/mL) & pH \\
\hline Feed Salt Soln. & $1.28 \mathrm{E}+08$ & 14 \\
\hline Strip Effluent \#1 & $8.50 \mathrm{E}+08$ & 5 \\
\hline Strip Effluent \#2 & $6.68 \mathrm{E}+08$ & 4 \\
\hline Strip Effluent \#3 & $2.38 \mathrm{E}+08$ & 5 \\
\hline DSS & $2.18 \mathrm{E}+07$ & 14 \\
\hline
\end{tabular}

\footnotetext{
${ }^{\Upsilon}$ This batch of solvent was originally prepared with no extractant as S2-NOBOB-T-WI (see WSRC-NB-2005-00060). The extractant was added later (see WSRC-NB-2007-00054).
} 
The analytical uncertainty on the ${ }^{137} \mathrm{Cs}$ activity is $10 \%$ and $\pm 1 \mathrm{pH}$ unit for the $\mathrm{pH}$ measurement.

\subsubsection{Washing of the Stripped Sample}

At the end of the ESS test, the organic residue from the strip contact test was taken through the washing step as directed from the customer. The washing step contacts the organic material with a $0.03 \mathrm{M} \mathrm{NaOH}$ solution for a 24 hour period. The organic phase was recovered and analyzed for ${ }^{137} \mathrm{Cs}$ activity. The aqueous phase was re-collected and submitted to $\mathrm{AD}$ for ${ }^{137} \mathrm{Cs}$ activity and $\mathrm{pH}$. The results of the post contacted solutions are shown in Table 11. Semi-volatile organic analysis (SVOA) was also used to analyze the aqueous material for residual organic from the wash. There is one unexpected result of a 3-ethoxy propanediol present in the aqueous phase after washing with $\mathrm{NaOH}$. The origin of this compound is thought to be a decomposition product from the Modifier but it is not clear the exact structure can be comprised from this. This compound is present in higher concentration due to high solubility in the aqueous solution as compared to the 4 -secbutyl phenol (SBP). After comparing the data, the Cs-7B Modifier is low compared with the partition concentration shown previously of $9.79 \mathrm{ppm}^{\text {xiv }}$ These results are shown in Table 12.

Table 11. Results from 0.03M NaOH Wash

\begin{tabular}{|l|l|}
\hline Analysis & Results \\
\hline${ }^{137}$ Cs activity Aq & $1.47 \mathrm{E}+06 \mathrm{dpm} / \mathrm{mL}$ \\
\hline${ }^{137}$ Cs activity Org & $3.46 \mathrm{E}+07 \mathrm{dpm} / \mathrm{mL}$ \\
\hline $\mathrm{pH}$ & 10 \\
\hline DF & $11.66^{\mathrm{a}}$ \\
\hline
\end{tabular}

Table 12. SVOA for Aqueous Component

\begin{tabular}{|l|l|l|}
\hline \multicolumn{1}{|c|}{ Analyte } & Concentration & \multicolumn{1}{c|}{ Comments } \\
\hline 3-ethoxy 1,2 propanediol & $5.7 \mathrm{ppm}$ & Org contaminant \\
\hline 4-(sec butyl) phenol & $2.8 \mathrm{ppm}$ & $\begin{array}{l}\text { Modifier } \\
\text { decomposition } \\
\text { product }\end{array}$ \\
\hline Cs-7B Modifier & $4.4 \mathrm{ppm}$ & From MCU solvent \\
\hline
\end{tabular}

\subsection{Conclusions}

Analysis of the Tank $21 \mathrm{H}$ sample indicates that the material does not display any unusual characteristics. In conjunction with the previous reports, ii the Tank $21 \mathrm{H}$ material is acceptable for processing in the ISDP process.

This report also covers the MST sorption and ESS results for the ISDP Salt Batch 6 feed sample. The following observations are made from the work.

\footnotetext{
${ }^{a}$ The temperature correction value utilized in this DF calculation for the wash step is the same as the extraction step.
} 
- A demonstration of the monosodium titanate removal of strontium and actinides provided acceptable 8 hour versus the standard 12 hour decontamination values for $\mathrm{Pu}$ and Sr of 2.84 and 30.76, respectively. Additionally, a MST concentration of 0.2 $\mathrm{g} / \mathrm{L}$ was utilized instead of the normal $0.4 \mathrm{~g} / \mathrm{L}$ based on changes made in the facility. These DF values are lower than previous tests due to shorter contact time and reduced amounts of MST.

- A demonstration of cesium extraction, scrubbing and stripping cesium mass transfer - intended to partially mimic the MCU operations - yielded behavior within acceptable norms. The measured distribution values are: 9.14, 2.716, 0.800, 0.0396, 0.0184, and 0.0247 for Extraction, Scrub \#1, Scrub \#2, Strip \#1, Strip \#2, and Strip \#3, respectively. The values indicate the cesium removal should be comparable to prior batches in MCU. 
SRNL-STI-2013-00034

Revision 0

\subsection{References}

${ }^{\mathrm{i}}$ T. B. Peters and S. D. Fink, "Results of Initial Analyses of the Macrobatch 6 Tank 21H Qualification Samples,” SRNL-STI-2012-00685, Rev. 0, November 2012.

ii T. B. Peters and S. D. Fink, "Sample Results from the Integrated Salt Disposition Program Macrobatch 6 Tank 21H Qualification Samples,” SRNL-STI-2012-00707, Rev. 0, December 2012.

iii S. E. Campbell, “Qualification of ISDP Salt Batch 6,” HLW-DWPF-TTR-2012-0012, October 18, 2012.

iv T. B. Peters and S. D. Fink, "Task Technical and Quality Assurance Plan for ISDP Salt Batch 6 Sample Qualification,” SRNL-RP-2012-00625, Rev. 0, October 11, 2012.

${ }^{v}$ S. E. Campbell, "Qualification and Sampling Strategy for ISDP Batch 5 to Obtain Compliance to 512-S, DWPF, Tank Farm, and Saltstone Waste Acceptance Criteria”, XESR-H-00347, November 17, 2011.

${ }^{\text {vi }}$ SRNL-NB-2012-00107 ISDP 6. Oct. 25, 2012. T. B. Peters.

${ }^{v i i}$ T. B. Peters and S. D. Fink, "Sample Results from the Integrated Salt Disposition Program Macrobatch 5 Tank 21H Qualification MST, ESS, and PODD Samples," SRNLSTI-2012-00207, Rev. 0, April 2012.

viii D. T. Hobbs, D. T. Herman, M. R. Poirier, "Decontamination Factors and Filtration Flux Impact to ARP at Reduced MST Concentration”, SRNL-STI-2012-00299, Rev. 0, June 2012.

${ }^{\text {ix }}$ Grubbs, F. E. Procedures for detecting outlying observations in samples. Technometrics 1969, 11, 1-21.

${ }^{\mathrm{x}}$ T. B. Peters, A. L. Washington, F. F. Fondeur, S. D. Fink, "Solvent Hold Tank Sample Results for MCU-11-314, MCU-11-315, MCU-11-316, MCU-11-317, MCU-11-318, and MCU-11-319”, SRNL-STI-2011-00301, June 2011.

${ }^{x i}$ T. B. Peters, F. F. Fondeur, S. D. Fink, "Solvent Hold Tank Sample Results for MCU11-1035, MCU-11-1036, MCU-11-1037, MCU-11-1038, MCU-11-1039 and MCU-111040”, SRNL-STI-2011-00593, Rev. 1, October 2011.

${ }^{x i i}$ T. B. Peters, S. D. Fink, "Results from Monosodium Titanate (MST) and ExtractionScrub-Strip (ESS) Testing of ISDP Macrobatch 3 Blend”, SRNL-STI-2010-00290, Rev. 0, May 2010.

xiii K. Adu-Wusu, D. D. Walker, T. B. Edwards, "Waste and Solvent Composition Limits for Modular Caustic-Side Solvent Extraction Unit (MCU)”, WSRC-TR-2005-00258, May 26, 2005.

${ }^{x i v}$ B. A. Moyer, S. D. Alexandratos, P. V. Bonnesen, G. M. Brown, J. E. Caton, L. H. Delmau, C. R. Duchein, T. J. Haverlock, T. G. Levitskaia, M. P. Maskarinec, F. V. Sloop, C. L. Stine, "Caustic-Side Solvent Extraction Chemical and Physical Properties Progress in FY 2000 and FY 2001”, ORNL-TM-2001-285, Feb. 2002. 